\title{
Placentation in Sigmodontinae: a rodent taxon native to South America
}

\author{
Phelipe O Favaron ${ }^{1}$, Anthony M Carter ${ }^{2}$, Carlos E Ambrósio ${ }^{3}$, Adriana C Morini ${ }^{1}$, Andrea M Mess ${ }^{1}$, \\ Moacir F de Oliveira ${ }^{4}$ and Maria A Miglino ${ }^{1 *}$
}

\begin{abstract}
Background: Sigmodontinae, known as "New World rats and mice," is a large subfamily of Cricetidae for which we herein provide the first comprehensive investigation of the placenta.

Methods: Placentas of various gestational ages ranging from early pregnancy to near term were obtained for five genera, i.e. Necromys, Euryoryzomys, Cerradomys, Hylaeamys, and Oligoryzomys. They were investigated by means of histology, immunohistochemistry, a proliferation marker, DBA-lectin staining and transmission electron microscopy.

Results: The chorioallantoic placenta was organized in a labyrinthine zone, spongy zone and decidua and an inverted yolk sac persisted until term. The chorioallantoic placenta was hemotrichorial. The interhemal barrier comprised fetal capillary endothelium and three layers of trophoblast, an outermost, cellular layer and two syncytial ones, with interspersed trophoblast giant cells (TGC). In addition, accumulations of TGC occurred below Reichert's membrane. The junctional zone contained syncytial trophoblast, proliferative cellular trophoblast, glycogen cells and TGC that were situated near to the maternal blood channels. In three of the genera, TGC were also accumulated in distinct areas at the placental periphery. PAS-positive glycogen cells derived from the junctional zone invaded the decidua. Abundant maternal uNK cells with positive response to PAS, vimentin and DBA-lectin were found in the decidua. The visceral yolk sac was completely inverted and villous.

Conclusion: The general aspect of the fetal membranes in Sigmodontinae resembled that found in other cricetid rodents. Compared to murid rodents there were larger numbers of giant cells and in some genera these were seen to congregate at the periphery of the placental disk. Glycogen cells were found to invade the decidua but we did not identify trophoblast in the walls of the deeper decidual arteries. In contrast these vessels were surrounded by large numbers of UNK cells. This survey of wild-trapped specimens from five genera is a useful starting point for the study of placentation in an important subfamily of South American rodents. We note, however, that some of these rodents can be captive bred and recommend that future studies focus on the study of time dated pregnancies.
\end{abstract}

\section{Background}

Muridae and Cricetidae are the most species-rich families of rodents, with around 600 species in each family [1]. For both taxa there are still important gaps in basic knowledge about reproductive biology. In particular, the development of the placenta is not well understood for the majority of species. Muridae includes several laboratory models, such as mouse and rat, for which placentation is very well documented [e.g., 2-9],

\footnotetext{
* Correspondence: miglino@usp.br

'Department of Surgery, School of Veterinary Medicine, University of Sao Paulo, Sao Paulo, Brazil

Full list of author information is available at the end of the article
}

yet $98 \%$ of the murid species have not been studied with regard to their placentation [10]. Cricetidae is even less well covered although some basic data is available for the golden hamster Mesocricetus auratus from the subfamily Cricetinae [11-13]. In addition, some aspects of placentation have been documented for members of the subfamily Arvicolinae, namely voles and lemmings [14,15], and the North American deer mouse Peromyscus maniculatus from the subfamily Neotominae $[15,16]$. But for the largest subfamily, the Sigmodontinae, with 377 recognized species in 74 genera [1], data on placentation is very sparse. The only species studied so far is Calomys callosus, which has been used as an

\section{Biomed Central}


experimental model for parasitological and other diseases [17-22].

Sigmodontine rodents form a monophyletic clade [23-25]. These rodents are largely confined to the Neotropics [26], and are often referred to as "New World rats and mice". They are known to transmit diseases to humans and domestic animals. Antibody prevalence indicates that sigmodontine species are reservoirs of Hantavirus in the several regions of Brazil and other parts of Latin America [27]. In addition, they are the most important reservoirs of zoonotic cutaneous leishmaniasis throughout their range [24]. For this reason they are generally considered as pests. On the other hand, sigmodontine rodents usually possess restricted ranges, and are vulnerable to habitat loss. Thus, they may serve as indicators for biodiversity purposes [28]. A better understanding of reproductive biology in these species is therefore desirable and needs to include a comprehensive analysis of placental development and structure.

We here provide a detailed study on placentation in five genera of sigmodontine rodents (Necromys, Euryoryzomys, Cerradomys, Hylaeamys and Oligoryzomys). Data on reproduction in this subfamily is sparse but where known gestation lasts 23 to 30 days, slightly longer than in mice, rats and other cricetids $[9,12,26,29]$. Placentas from various gestational stages, ranging from early pregnancy to near term, have been studied by a variety of techniques including immunohistochemistry, DBA-lectin staining and transmission electron microscopy. The findings are compared and contrasted with what is known about placentation in other murid and cricetid rodents.

\section{Methods}

\section{Material}

Placentae from five genera of sigmodontine rodents were investigated: Necromys, Euryoryzomys, Cerradomys, Hylaeamys and Oligoryzomys (Table 1). The nomenclature follows a recent revision of the Oryzomys complex by Weksler et al. [25]. Most of the material was obtained from the collection of the Museum of Zoology, University of Sao Paulo (MZUSP). Additional material of Necromys was obtained from a breeding group at the Universidade Federal Rural do Semi Árido, Mossoró, Rio Grande do Norte (CEMAS). Euryoryzomys was live-trapped at Sao Joaquim da Barra, Sao Paulo (SJB). The identification of Euryoryzomys was made by the Laboratory of Ecology and Evolution, Butantan-Institute, Sao Paulo. Voucher material was given to the Museum of Veterinary Anatomy (MAV), University of Sao Paulo. The other material is now housed at the School of Veterinary Medicine, University of Sao Paulo.
The museum specimens had been fixed in formaldehyde and stored in 70\% alcohol. Tissue was processed by standard methods, embedded in paraffin (Paraplast; Oxford Labware, St Louis, MO, USA) and sectioned at 5 $\mu \mathrm{m}$ using an automatic microtome (Leica, RM2155, Germany).

\section{Histology, immunohistochemistry and lectin staining}

Sections were stained with hematoxylin and eosin (HE), Masson's trichrome, picrosirius, and periodic acid-Schiff (PAS). In addition, immunohistochemistry was performed following the approaches used in previous studies from our laboratory [see 30,31]. Cytokeratin was used to identify trophoblast cells and was detected by a rabbit polyclonal antibody (1:300; PU071-UP, Biogenex, San Ramon, California, U.S.A.). Mouse monoclonal antihuman primary antibodies were used to detect vimentin (1:300; V9, sc-6260, Santa Cruz Biotechnology, Santa Cruz, California, USA), $\alpha$-smooth muscle actin (1:300; Clone 1A4, DakoCytomation, Carpinteria, California, USA), and PCNA (1:400; PC10, sc-56, Santa Cruz Biotechnology, Santa Cruz, California, USA). Negative controls were performed using anti-mouse IgG (1:500; AP308F, Chemicon International Temecula, California, USA) as the primary antibody solution.

In addition, samples from three species (Necromys lasiurus, Hylaeamys megacephalus, and Cerradomys gr. subflavus,) were stained using a Dolichos biflorus (DBA) lectin to identify mature uNK cells, following the protocol described by Zhang et al. [4].

\section{Transmission electron microscopy}

Samples for transmission electron microscopy, derived from freshly obtained material of Necromys and Euryoryzomys, were fixed in $2.5 \%$ glutaraldehyde. Tissues were maintained in this solution for $48 \mathrm{~h}$ and post-fixed for 2 $\mathrm{h}$ in $2 \%$ phosphate-buffered osmium tetroxide ( $\mathrm{pH} 7.4$, for $2 \mathrm{~h}$ ), then washed in phosphate buffer $(3 \times 10 \mathrm{~min})$ and immersed in $3 \%$ uranyl acetate solution overnight. After being re-washed in buffer $(3 \times 10 \mathrm{~min})$, tissues were dehydrated in alcohol and immersed in propylene oxide for $10 \mathrm{~min}$. Finally, the samples were embedded in Spurr's Resin (Polysciences, Warrington, PA, USA). Ultrathin sections were made on an automatic ultramicrotome (Ultracut R, Leica Microsystems, Germany), contrasted with $2 \%$ uranyl acetate and $0.5 \%$ lead citrate and studied in a transmission electron microscope (Morgagni 268D, FEI Company, The Netherlands; Mega View III camera, Soft Imaging System, Germany).

\section{Results}

\section{Macroscopic structure}

In all taxa investigated the chorioallantoic placenta was situated at the antimesometrial side of the bicornuate 
Table 1 Material collected with values

\begin{tabular}{|c|c|c|c|c|c|c|c|}
\hline \multirow[b]{2}{*}{ Species and Collection Number } & \multirow[b]{2}{*}{ Geographical Origin } & \multicolumn{2}{|c|}{ Fetuses } & \multicolumn{4}{|c|}{ Placentae } \\
\hline & & $\mathrm{FL}(\mathrm{cm})$ & $\mathrm{FW}(\mathrm{g})$ & PW (g) & PV (ml) & $\mathrm{PL}(\mathrm{cm})$ & $\mathrm{PD}(\mathrm{cm})$ \\
\hline \multicolumn{8}{|l|}{ Necromys lasiurus } \\
\hline MAV (CEMAS 03) & Mossoro, RN & Implantation & - & - & - & - & - \\
\hline MAV (CEMAS 04) & Mossoro, RN & 0.5 & 0.148 & 0.052 & 0.2 & 0.5 & 0.3 \\
\hline MAV (CEMAS 05) & Mossoro, RN & 0.6 & 0.151 & 0.065 & 0.2 & 0.6 & 0.4 \\
\hline MZUSP (APC 1140) & Santa Bárbara, SP & 1.3 & 0.377 & 0.142 & 0.4 & 1.1 & 0.9 \\
\hline MZUSP (APC 1246-1) & Serra Geraldo Tocantins, TO & 3.1 & 3.354 & 0.696 & 0.9 & 1.4 & 0.7 \\
\hline MZUSP (APC 1246-2) & Serra Geraldo Tocantins, TO & 3.1 & 3.432 & 0.407 & 0.5 & 1.3 & 1.1 \\
\hline MZUSP (APC 1246-3) & Serra Geraldo Tocantins, TO & 2.5 & 1.964 & 0.324 & 0.5 & 1.2 & 0.6 \\
\hline MAV (CEMAS 01) & Mossoro, RN & near term & - & - & - & - & - \\
\hline MAV (CEMAS 02) & Mossoro, RN & near term & - & - & - & - & - \\
\hline \multicolumn{8}{|l|}{ Cerradomys gr. subflavus } \\
\hline MZUSP (APC 1157) & Santa Barbara, SP & 2.8 & 5.223 & 0.627 & 0.9 & 1.5 & 1.2 \\
\hline MZUSP (APC 1177) & Santa Barbara, SP & 2.0 & 0.834 & 0.897 & 1.0 & 1.2 & 0.9 \\
\hline MZUSP (APC 1177-1) & Santa Barbara, SP & 2.4 & 0.329 & 0.334 & 0.5 & 1.1 & 0.8 \\
\hline MZUSP (APC 1177-2) & Santa Barbara, SP & 2.2 & 0.312 & 0.299 & 0.5 & 1.0 & 0.7 \\
\hline \multicolumn{8}{|l|}{ Euryoryzomys sp. } \\
\hline MAV (SJB 01) & São Joaquim da Barra, SP & 1.6 & 0.907 & - & - & - & - \\
\hline MAV (SJB 02) & São Joaquim da Barra, SP & 1.8 & 0.933 & - & - & - & - \\
\hline \multicolumn{8}{|l|}{ Hylaeamys megacephalus } \\
\hline MZUSP (APC 1022-1) & Serra das Araras, MT & - & - & 0.222 & 0.1 & 1.0 & 0.5 \\
\hline MZUSP (APC 1022-3) & Serra das Araras, MT & - & - & 0.095 & 0.1 & 1.0 & 0.6 \\
\hline MZUSP (MRT 08415) & Goiania, GO & 1 & 0.107 & 0.209 & 0.4 & 0.9 & 0.6 \\
\hline MZUSP (MRT 08408) & Goiania, GO & 2.2 & 1.082 & 0.538 & 0.9 & 1.1 & 1.0 \\
\hline \multicolumn{8}{|l|}{ Oligoryzomys sp. } \\
\hline MZUSP 32729-1 & Cotia and Ibiuna, SP & 2.4 & 1.186 & 0.079 & 0.2 & 1.2 & 0.8 \\
\hline MZUSP 32729-4 & Cotia and Ibiúna, SP & 2.3 & 1.188 & 0.174 & 0.3 & 1.1 & 0.8 \\
\hline MZUSP 31167 & Piedade, SP & 1.0 & 0.118 & 0.051 & 0.1 & 0.6 & 0.5 \\
\hline MZUSP 32735 & Piedade, SP & 0.5 & 0.025 & 0.075 & 0.1 & 0.6 & 0.5 \\
\hline
\end{tabular}

Fetal length (FL), fetal weight (FW), placental weight (PW), placental volume (PV), placental length (PL) and placental diameter (PD). Most specimens were from the collection of the Museum of Zoology, University of Sao Paulo, SP, Brazil (MZUSP) with temporary museum numbers given in brackets. The nomenclature follows a recent revision of Oryzomys by Weksler et al. [25]. Fresh material was collected at CEMAS, Mossoro, RN, and in São Joaquim da Barra (SJP), SP.

uterus and a choriovitelline placenta persisted throughout gestation (Figures $1 \mathrm{~A}-\mathrm{C}$ ). The embryos were situated towards the mesometrial side of the uterus. The definitive chorioallantoic placenta was discoidal to ovoid in shape. The junction between the chorion and the uterus was restricted to an area at the antimesometrial side of the uterus (Figures 1B,C). A delicate umbilical cord was attached to the center of the placental disk. The visceral yolk sac was completely inverted at all stages (Figures 1B,C).

\section{Labyrinth}

The chorioallantoic placenta was composed of a labyrinth situated towards the fetal or the mesometrial side of the uterus and an inner junctional zone (or trophospongium) adjacent to the decidua (Figures 1B,C). The labyrinth was vascularized from both the maternal and fetal circulations. The maternal blood was found to flow through tubular channels, the maternal blood lacunae or blood channels (Figure 2A), also found in the junctional zone (Figure 2B). The fetal vessels had intact endothelium, resulting in vimentin-positive response of the labyrinth (Figures 2C,D). The walls of the lacunae were composed of syncytial and cellular trophoblast. In addition to normal-sized trophoblasts, larger cells were interspersed, the sinusoidal trophoblast giant cells (Figure 2A). Thus, the barrier varied in thickness, including thinner and thicker regions. In addition, groups of TGC occurred at the outer border of the labyrinth, adjacent to Reichert's membrane.

\section{Interhemal barrier}

The labyrinth is the region of feto-maternal exchange. Trophoblastic trabeculae formed the barrier between the fetal and maternal circulations. In contrast to the fetal system that had intact capillaries, the maternal blood flowed through trophoblast-lined channels (Figures 3AC). As mentioned above, the thickness of the placental 


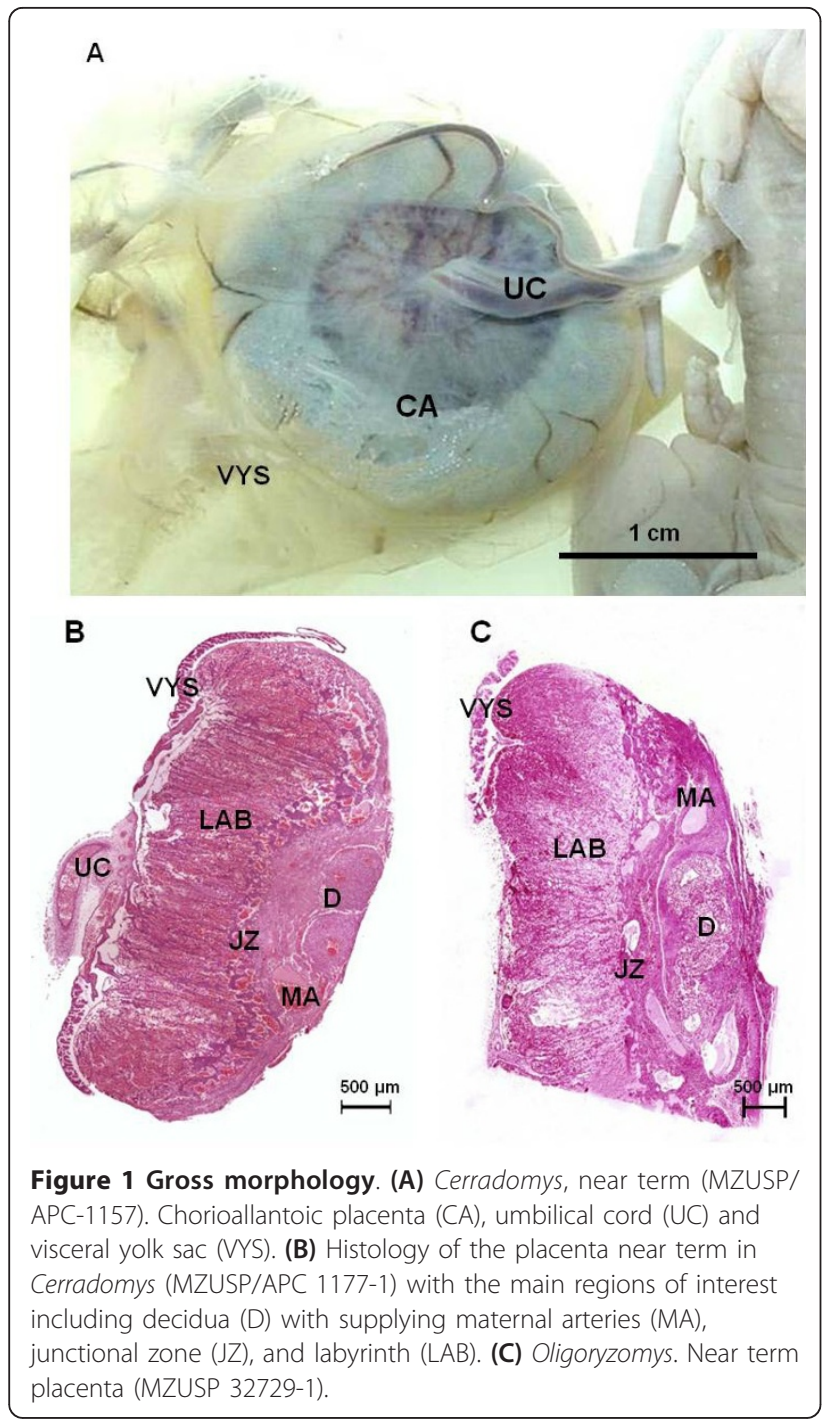

barrier varied greatly in all taxa investigated, including very thin areas but also thicker parts (Figure 2A). However, the minimal thickness in the two taxa that were studied by electron microscopy was found to be approximately $2.5 \mu \mathrm{m}$ in Necromys and $7 \mu \mathrm{m}$ in Euryoryzomys. The placental barrier comprised three trophoblastic layers (Figures 3B-F), resulting in a hemotrichorial condition. The outermost layer (TI) lined the maternal blood channels. It was cellular in nature (Figures 3E,F). In places this layer (TI) was reduced to a very thin flange, but with projections towards the maternal blood (Figures 3E,F). The middle layer (TII) was much thicker and only loosely attached to the layer above it. It was syncytial in nature (not shown). However, an irregularly folded structure was present. Finally, the innermost layer (TIII) was likewise syncytial (Figures $3 \mathrm{~B}, \mathrm{C})$. It was very closely attached to the neighboring layer (TII), including tight and intermediate junctions as

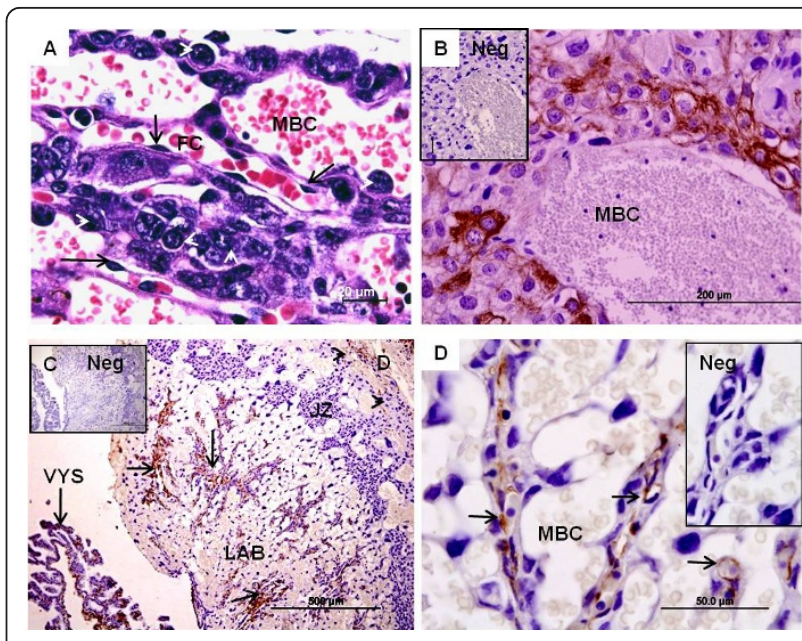

Figure 2 Main regions of the chorioallantoic placenta. (A) Cerradomys, near term (MZUSP/APC 1177-1). HE. Trophoblast layers separated maternal blood channels (MBC) and fetal capillaries in the labyrinth; the latter with intact endothelium (arrows). The placental barrier varied, possessing very thin areas and some thicker regions that included sinusoid trophoblast giant cells (arrowheads). (B) Necromys, near term (MAV/CEMAS 01). Immunohistochemistry for cytokeratin. In contrast to the labyrinth, the junctional zone did not possess fetal vessels. The maternal blood channels in this area were associated with trophoblast. (C) Necromys in mid gestation (MZUSP/ APC 1140). Immunohistochemistry for vimentin showed positive response for the fetal blood vessels (arrow) in the labyrinth (LAB), indicating an intact endothelium. In the visceral yolk sac (VYS) mesoderm was stained. In contrast, the maternal blood system of the labyrinth and junctional zone (JZ) lack endothelium, resulting in the vimentin-negative response of the junctional zone. In the decidua (D), maternal cells of mesenchymal origin were stained (arrow heads). (D) Necromys in mid gestation (MZUSP/APC 1140). Higher magnification of the labyrinth. Fetal vessels (arrow) ran inside the trophoblastic (vimentin-negative) layers that lined the maternal blood channels.

well as desmosomes (Figure 3D). Moreover, this layer (TIII) had a strong connection to the basement membrane of the fetal capillary endothelium (Figure 3D). In the areas of the labyrinth that were characterized by a thicker barrier between the two circulations, additional trophoblast and sinusoidal trophoblast giant cells were present below the innermost layer (TIII). It was mostly cellular.

\section{Junctional zone and giant cell region}

The junctional zone (Figures 4A,B) abutted the decidual region. It consisted largely of spongiotrophoblast. In most areas, both syncytial and cellular trophoblast were found (Figure 4C), but in some places only a thin syncytial layer was associated with the maternal blood spaces (Figure 4D), whereas in others there were trophoblast cells. The trophoblast cells were actively proliferative, as indicated by PCNA-staining. In early pregnancy, such proliferative trophoblast clustered as nests inside the 

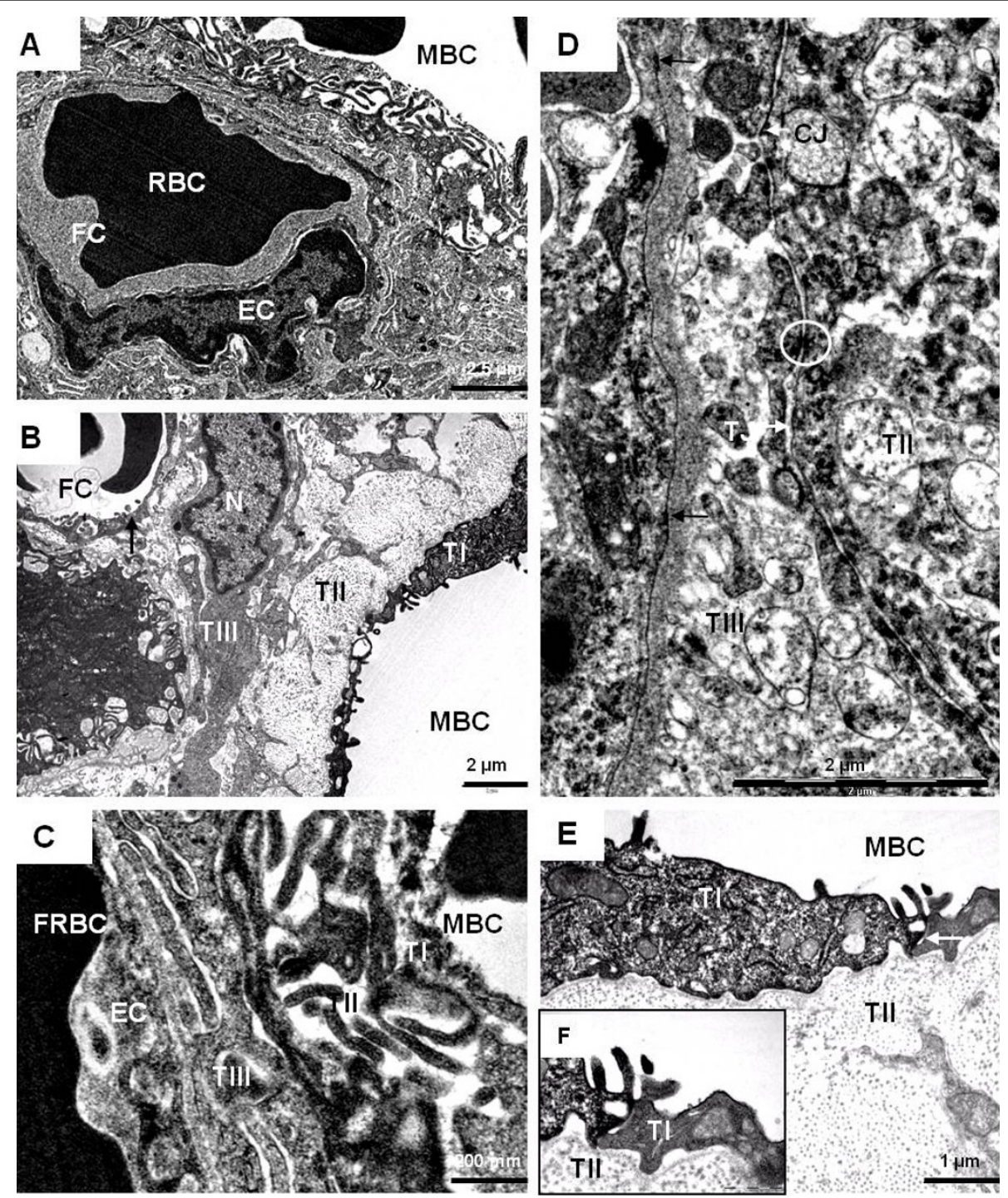

Figure 3 Ultrastructure of the labyrinth in mid gestation. (A) Necromys (MZUSP/APC 1246-3). The placental barrier separated a maternal blood channel (MBC) and a fetal capillary (FC) with intact endothelium (EC) and a red blood cell (RBC). (B) Necromys (MZUSP/APC 1246-3). The placenta comprised three trophoblastic layers (TI, TII and TIII). (C) Euryoryzomys (MAV/SJB 02). The hemotrichorial placenta. (D) Necromys (MZUSP/ APC 1246-3). There was a strong contact between layer TIII and the basement membrane of the endothelial cell (arrow). Different types of junctions occurred between trophoblast layers TII and TIII, including tight junctions (TJ), intermediate junctions (CJ) and desmosomes (circle). (E) Necromys (MZUSP/APC 1246-3). The outermost layers in detail. (F) Euryoryzomys (MAV/SJB 02). Two cells belonging to layer TI.

junctional zone (Figure 4E), whereas it was more frequent and distributed throughout this region in more advanced pregnancies (Figures 4F,G). Moreover, trophoblast giant cells were dispersed within the junctional zone, closely associated with the maternal blood channels (Figures 4H). They had large nuclei and prominent chromatin. The largest amount of trophoblast giant cells inside the junctional zone was found in Oligoryzomys and Necromys, in both closely associated with the spongiotrophoblast. In the three other genera of sigmodontine rodents that had fewer trophoblast giant cells inside the junctional zone - Cerradomys, Hylaeamys and
Euryoryzomys - trophoblast giant cells were found to be accumulated in distinct regions at the periphery of the placental disk (Figures 5A,B). All investigated genera of sigmodontine rodents possessed a continuous band of trophoblast giant cells, situated between the decidua and the junctional zone (Figure $5 \mathrm{C}$ ). This band was connected to the region of accumulated trophoblast giant cells in the three above mentioned genera. The giant cells were mostly bi- or multinucleated in nature.

Neither the spongiotrophoblast nor the trophoblast giant cells associated with the junctional zone showed positive reactions to PAS staining. This distinguished 

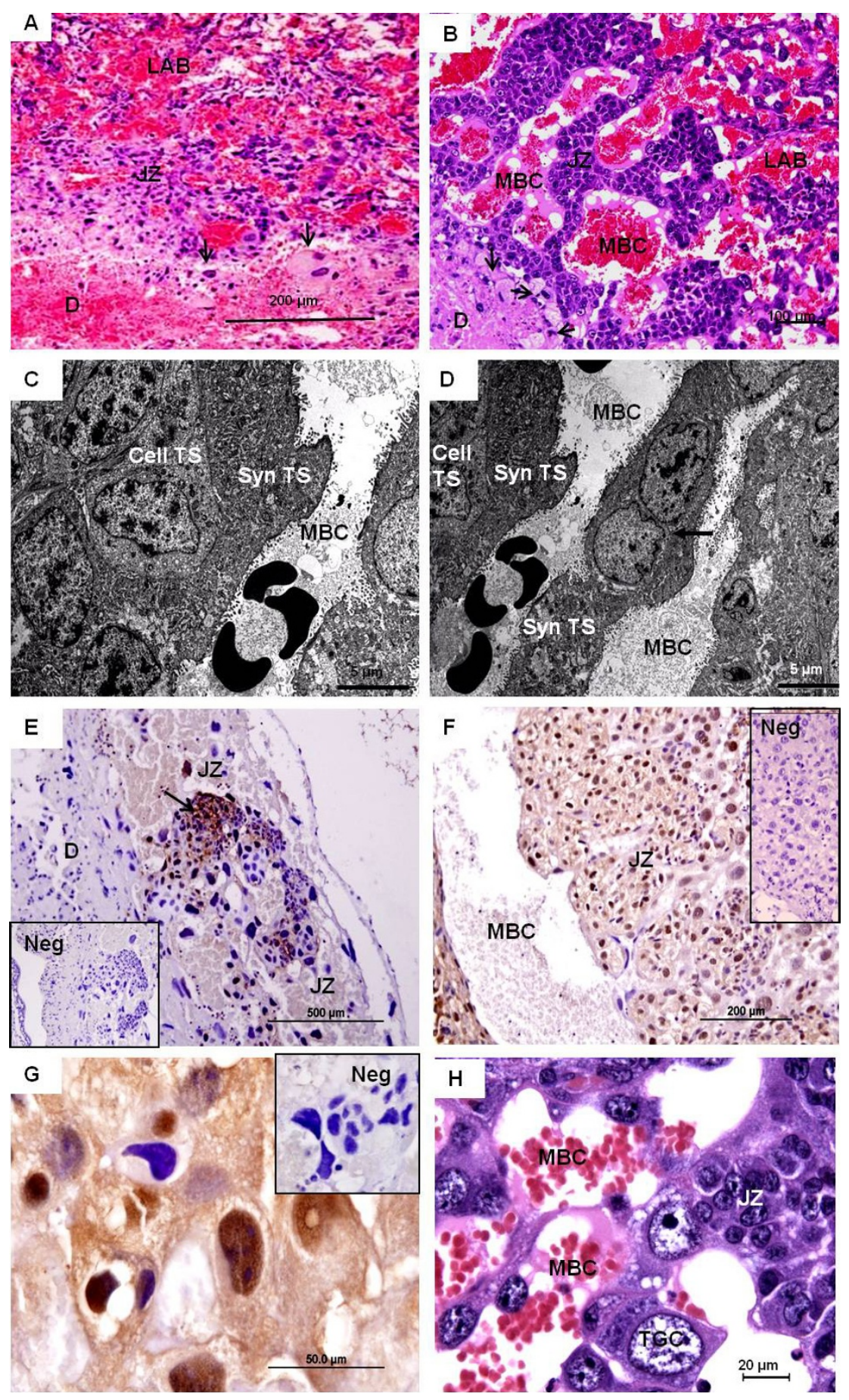

Figure 4 The junctional zone. (A) Necromys, early pregnancy (MAV/CEMAS 05). HE. The junctional zone (JZ) with simple structure facing towards the decidua. The border was not sharp with trophoblast derivatives (arrows) invading into the decidua. (B) Cerradomys, near term (MZUSP/APC 1157). The junctional zone had a folded structure arranged around the maternal blood channels (MBC). (C) Necromys, near term (MAV/CEMAS 02). TEM. Syncytial trophoblast (Syn TS) lined the maternal blood channels (MBC), associated with underlying cellular trophoblast (Cell TS). (D) Necromys, near term (MAV/CEMAS 02). TEM. In places the trophoblast separating the maternal blood spaces was represented only by a thin syncytial layer (arrow). (E) Necromys in early pregnancy (MAV/CEMAS 05). PCNA. Clustered groups of proliferating trophoblast cells (arrow) occurred in the junctional zone. (F) Necromys in mid gestation (MZUSP/APC 1246-1). PCNA. In more advanced stages, proliferating cells were widespread in the junctional zone. (G) Necromys in mid gestation (MZUSP/APC 1246-1). PCNA. Higher magnification. (H) Cerradomys, near term (MZUSP/APC 1157). HE. Among the spongiotrophoblast in the junctional zone, trophoblast giant cells (TGC) occurred. They were close to the maternal blood spaces and had large nuclei and prominent chromatin. 

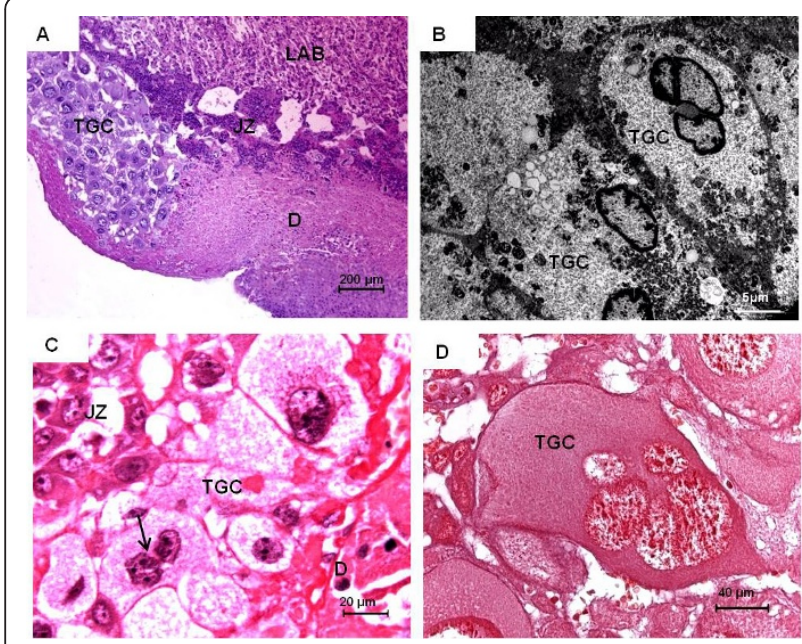

Figure 5 Giant cells. (A) Euryoryzomys in mid gestation (MAV/SJB 01). HE. Trophoblast giant cells (TGC) were accumulated at the outer areas of the placental disk, adjacent to the labyrinth (LAB) and junctional zone (JZ). (B) Euryoryzomys in mid gestation (MAV/SJB 02). TEM. Trophoblast giant cells at higher magnification. These cells were binucleate in nature. (C) Cerradomys, near term (MZUSP/APC 1177-1). HE. A continuous layer of trophoblast giant cells (TGC) was situated between the junctional zone (JZ) and the decidua (D). Some cells were binucleate (arrow). (D) Oligoryzomys, near term (MZUSP 32729-1). HE. Some trophoblast giant cells were multinucleate.

them from another type of cell, the so-called glycogen cells, the only type of fetal cell that showed positive reaction to PAS (Figure 6A). The glycogen cells were present inside the junctional zone as well as on the outer border, from which they invaded into the decidual region (Figures 6A-B). This extraplacental trophoblast was identified by cytokeratin-immunopositivity (Figure $6 \mathrm{C})$, and was vimentin-negative.

\section{Decidua and maternal blood supply}

The uterine spiral arteries entered the placenta in the decidual region (Figure 7A). As indicated by immunohistochemistry for vimentin, the mesometrial arteries possessed an intact endothelium (Figure 7B). In contrast, the endothelium of the maternal vessels near the placental disk was not completely intact. Remnants of the endothelium were detected by using vimentin staining (Figure $7 \mathrm{C}$ ). These findings suggested that the process of trophoblast invasion was restricted to regions adjacent to the placenta. Closely associated with the maternal arteries of the decidua in all species examined, there was a large amount of both smaller and larger cells that possessed PAS-positive granules (Figures 8A, B). Such cells were often found closely grouped together. In some of these cells more than one nucleus was present (Figure 8B). In addition to PAS, these cells reacted positively for vimentin (Figure $8 \mathrm{C}$ ), indicating

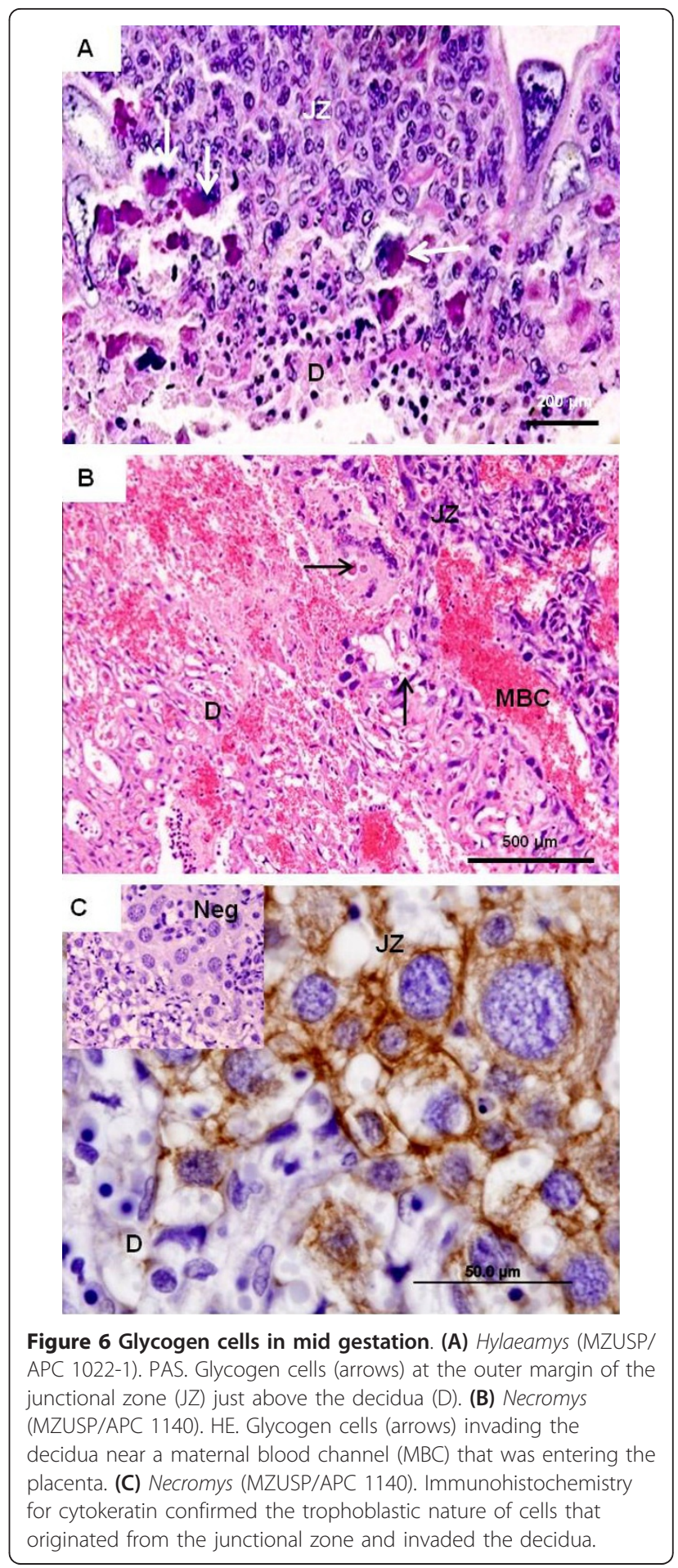

that they were derived from mesenchymal tissue and thus must be of maternal origin. They were identified as uterine natural killer cells (uNK cells). In early pregnancy such PAS-positive and vimentin-positive uNK cells were also found near the developing placental disk (Figure 8D). Cells associated with the maternal arteries 


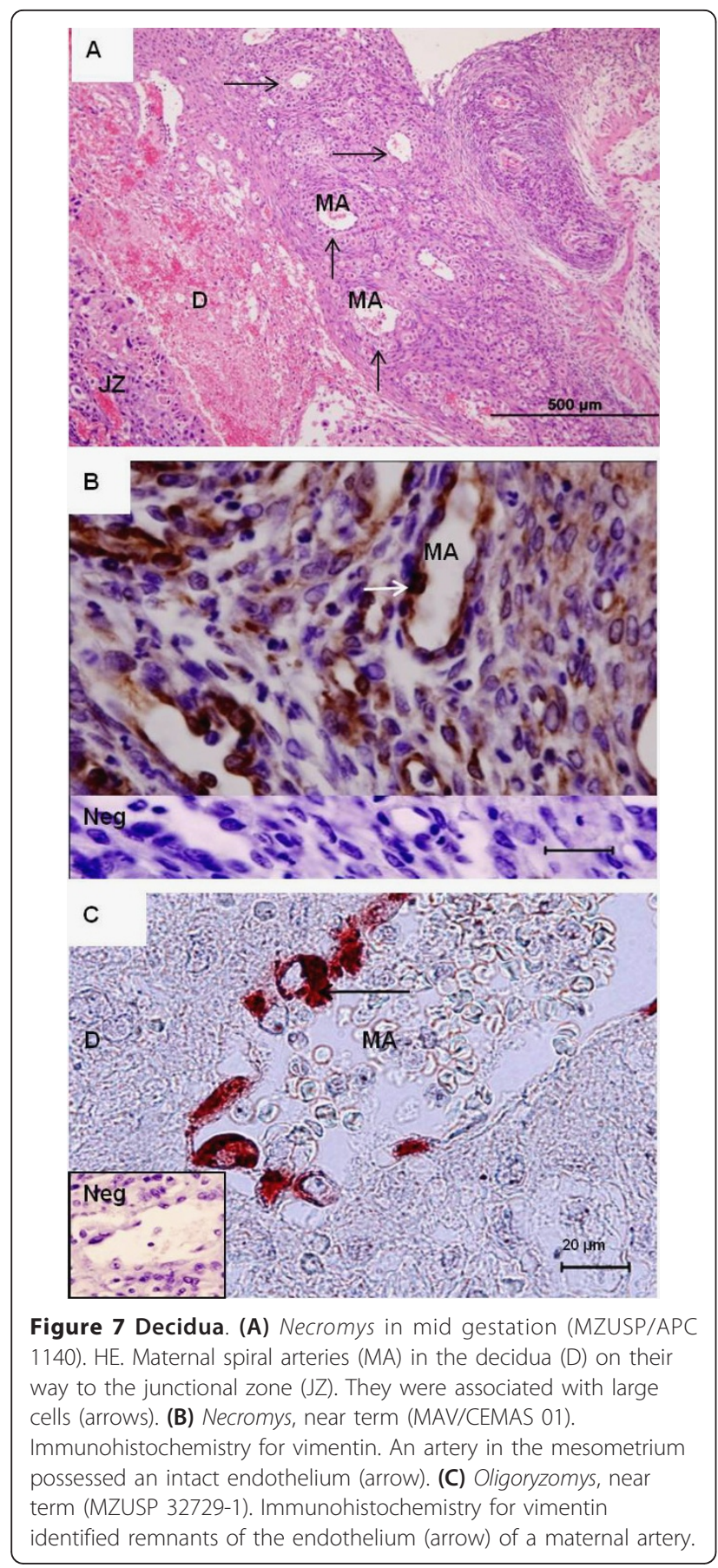

were not cytokeratin-positive (Figure 8E). The data once more supported their identification as uNK cells and indicated the restricted mode of trophoblast invasion into the decidua. In detail, the uNK cells mostly had large nuclei with irregular or spherical shape and some glycogen granules (Figure 8F). Using DBA-lectin staining (a phenotypic marker for uNK cells), we were able to detect positively reacting uNK cells associated with the blood vessels and inside the decidua (Figure 9A,B).
However, DBA-lectin staining in sigmodontine rodents was not specific to uNK cells, marking also cells inside the labyrinth, the endothelium of the fetal capillaries in particular (Figures 9C,D), as well as the visceral yolk sac epithelium (Figure 9E).

\section{The visceral and parietal yolk sac}

An inverted yolk sac placenta was present throughout pregnancy. It was closely attached to the labyrinthine region of the chorioallantoic placenta. The mostly onelayered parietal yolk sac covering was associated with a well-developed Reichert's membrane (Figures 10A-C). Especially in early to mid gestation the visceral yolk sac was highly villous (Figures 10C,D). The outer layer of the yolk sac consisted of visceral endoderm cells with cuboidal shape. The yolk sac endoderm cells reacted positively to PAS, including plenty of granular vesicles. Masson's Trichrome staining in Cerradomys suggested hemophagous activity (Figure 10D). In all species investigated, the cells of the yolk sac endoderm were separated by a basement membrane from the underlying mesoderm, which was well vascularized by vitelline blood vessels (Figures 10C, 11A). The nuclei of the visceral yolk sac endoderm were situated near the base of the cells. Their apical surface possessed numerous microvilli (Figure 11A,B). No coated pits were found. The cytoplasm included many rough endoplasmic reticulum cisterns, some glycogen granules, and vesicle-like vacuoles as well as scattered dense droplets with a great variability of shape and size (Figures 11B-D). In addition, intracellular spaces were evident in the endodermal cells (Figure 11D). The vitelline vessels included capillaries with fenestrated regions of endothelium (Figures 11E,F).

\section{Discussion}

Sigmodontinae is a South American radiation of cricetid rodents. Placentation in this speciose subfamily has been little studied and information is limited to a single species Calomys callosus [17-22]. Our aim therefore was to study a broader sample. Whilst we were able to study different gestational stages from five genera these were collected mainly in the wild. In contrast to studies of laboratory rodents we did not have carefully spaced specimens of known gestational age.

As in other murid and cricetid rodents, the chorioallantoic placenta consisted of three readily identifiable zones: labyrinth, junctional zone and decidua. An inverted choriovitelline or yolk sac placenta persisted until term. Because this basic design resembles that of the mouse, for which placental development and cell lineages are best understood [2,3,5-8,32-38], our findings are discussed in relation to this species as well as to other cricetid rodents such as the golden hamster, lemming and deer mouse [13-16]. 

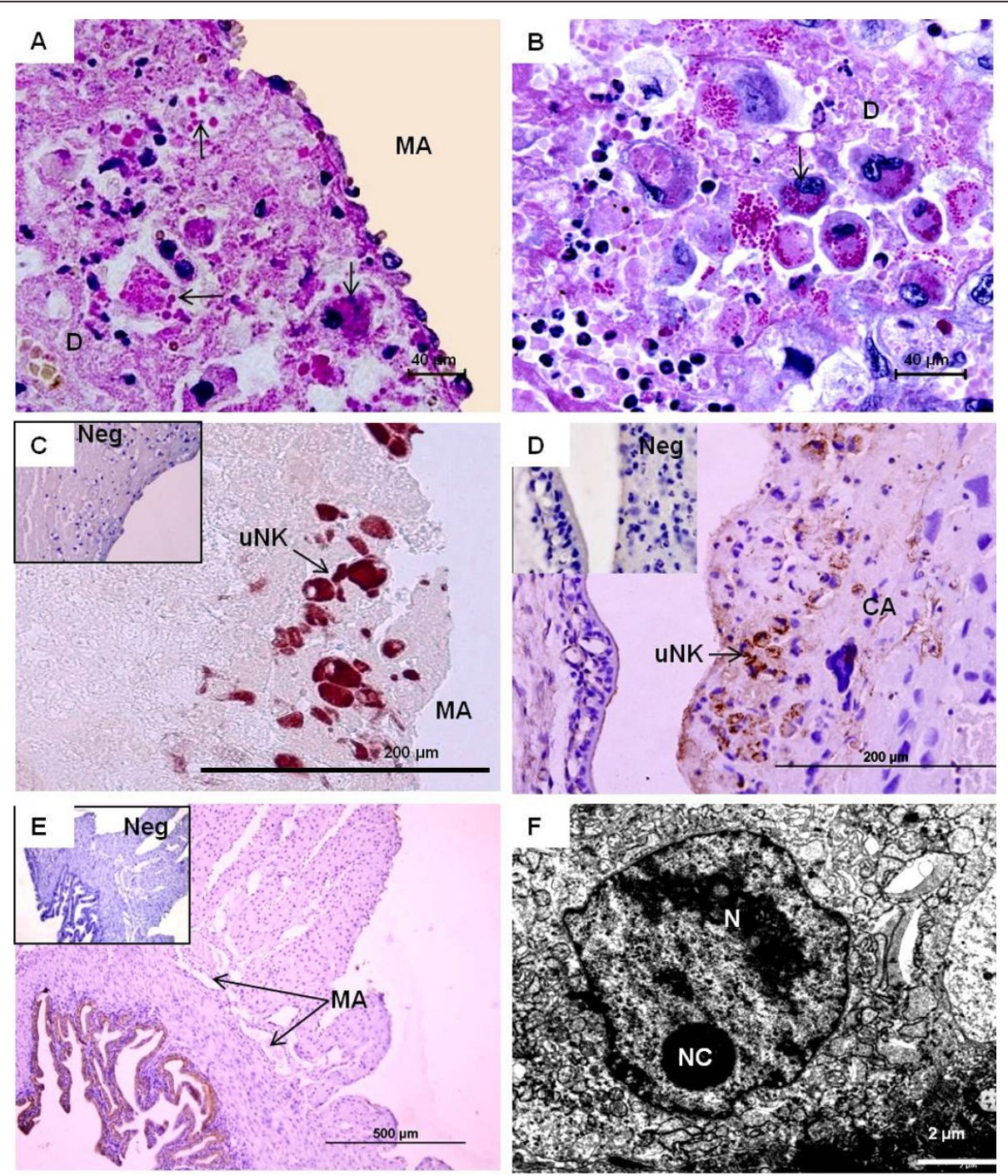

Figure 8 Uterine natural killer (uNK) cells. (A/B) Oligoryzomys in mid gestation (MZUSP 31167). PAS-positive cells accumulated near the maternal blood vessel (MA) in the decidua (D). Some were binucleated (arrows). (C) Oligoryzomys in early pregnancy (MZUSP 32735). Positive response to vimentin indicated that the cells were of mesenchymal origin, representing maternal uNK cells, not trophoblast. (D) Necromys in early pregnancy (MAV/CEMAS 04). Vimentin. In early gestation, the uNK cells were frequent also near to the outer margin of the placental disk (CA), which consisted of spongiotrophoblast and was vimentin-negative. (E) Necromys in early pregnancy (MAV/CEMAS 04). Immunostaining for cytokeratin. The negative response indicated that the invasion of trophoblast cells was limited to areas near the placenta. (F) Euryoryzomys in early pregnancy (MAV/SJB 01). TEM. The uNK cells in the decidua possessed large spherical nuclei (N) with irregular shape and distinct nucleoli (NC).

\section{Labyrinth and interhemal barrier}

The labyrinth consisted of maternal blood channels enclosed by trophoblast and running roughly parallel to fetal capillaries. As in other murid [16] and cricetid $[11,12,15,16,21]$ rodents, there were three layers of trophoblast, the inner two syncytial and the outer one cellular. Details of the structure of the interhemal barrier, such as the variation in thickness and the complex infolding of layer TII, were similar to what has been described in other subfamilies of cricetid rodents $[12,17]$. In the mouse all three trophoblast layers are derived from the same lineage [6]. They have distinct patterns of gene expression, however, and form discrete populations early in development [34]. Whilst we did find giant cells in the labyrinth, it remains to be shown if they are equivalent to the sinusoidal giant cells identified in the mouse on the basis of gene expression and polyploidy [34,37]. Although a hemotrichorial placenta is present in all murid and cricetid rodents so far examined, there are seven known variants of the interhemal barrier in rodents [39] and our previous analysis suggested that the hemotrichorial type of barrier is a derived character state [39]. 


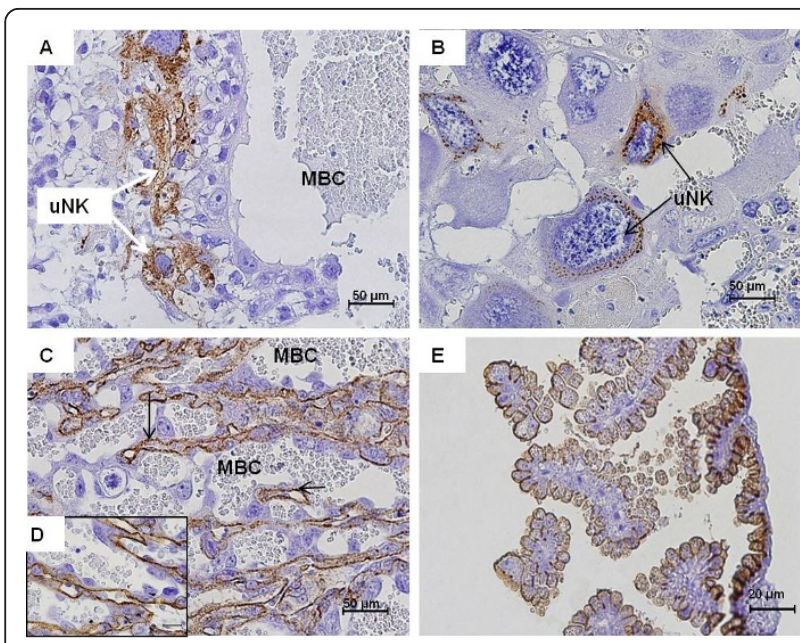

Figure 9 DBA-lectin staining in Cerradomys in mid gestation (MZUSP/APC 1177). (A) Positively reacting cells in the decidua that were usually in close association with maternal blood vessels. (B)

They possessed large amounts of granules and represented mature uNK cells. (C) DBA-lectin staining also marked cells inside the labyrinth, particularly the endothelium of the fetal capillaries (arrow). (D) The same at higher magnification. (E) The visceral yolk sac epithelium was stained by DBA-lectin.

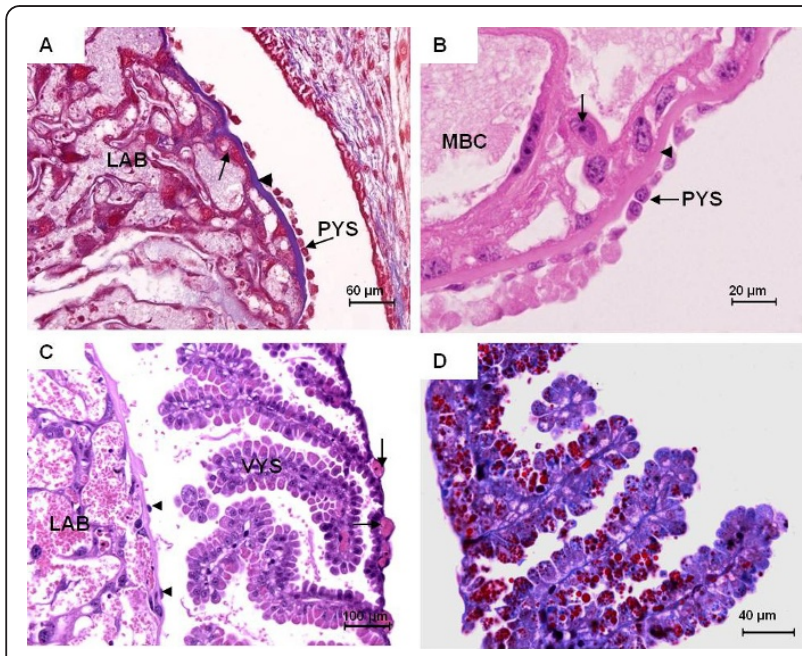

Figure 10 Parietal and visceral yolk sac. (A) Necromys in early pregnancy (MAV/CEMAS 04). Masson's Trichrome. The parietal yolk sac (PYS) was one layered and associated with a well-developed Reichert's membrane (arrowhead). (B) Necromys in early pregnancy (MAV/CEMAS 05). HE. Adjacent to the labyrinth and its maternal blood channels (MBC), trophoblast giant cells (arrow) were present. (C) Cerradomys in mid gestation (MZUSP/APC 1177-2). HE. The visceral yolk sac (VYS) was villous and supplied by vitelline blood vessels (arrows). It was close to the placental disc and the very thin parietal yolk sac that covered it (arrowheads). (D) Cerradomys in mid gestation (MZUSP/APC 1177-2). Masson's Trichrome. Positively reacting endodermal cells that were partly binucleate.

\section{Junctional zone}

As in other murid and cricetid placentae [6,13,33], there was a prominent junctional zone devoid of fetal vessels but with large trophoblast-lined maternal blood spaces. Two distinct types of trophoblast are found here: spongiotrophoblasts and glycogen cells. They were long thought to have a common origin but glycogen cells may be derived from precursors in the ectoplacental cone that, like them, express protocadherin 12 [40]. In the mouse placenta at E16.5 about $40 \%$ of the spongy zone is made up of glycogen cells but the proportion diminishes towards term [3]. We found relatively few glycogen cells in our specimens but this was difficult to interpret since gestational ages were not known.

\section{Trophoblast giant cells}

The classical giant cells of the rodent placenta, first recognized by their large size and high degree of polyploidy [41], are now referred to as parietal TGCs [34]. A few of them, sometimes known as primary giant cells, are derived from the mural trophectoderm, but the majority comes from the Tpbpa-negative lineage of the polar trophectoderm [6]. In the mouse they form a nearly continuous layer that marks the boundary between fetal and maternal tissues, although this boundary is breeched once the glycogen cells begin to invade the decidua. As expected, parietal TGCs were found at this location in the sigmodont placenta. In addition, in three genera, the giant cells formed a layer many cells thick at the margin of the disk. A similar accumulation of giant cells is not known from mouse placenta where the total population of parietal TGCs is estimated to be only twenty thousand [3].

\section{Decidua and maternal blood vessels}

The extent to which trophoblast invades maternal blood vessels differs among murid rodents [9]. In the mouse it has been thought for many years that trophoblast invasion is confined to vessels in the fetal part of the placenta [42]. In contrast, in the rat, trophoblast invasion by the endovascular route plays an important part in remodeling of the uterine spiral arteries $[9,43]$. More recently it has been recognized that in mouse some trophoblasts migrate by a perivascular route and end up in the lumen of the maternal arteries [2,34]. Trophoblast invasion of maternal arteries certainly occurs in the golden hamster, a cricetid rodent $[13,44]$. In contrast, in sigmodonts, we did not find cytokeratin-positive cells in the walls of the spiral arteries and the vessel endothelium was largely intact. Cytokeratin-positive cells were not found in the mesometrial triangle. Whilst this is suggestive of shallow trophoblast invasion in sigmodonts, it clearly is an aspect that needs to be systematically explored in specimens of known gestational age. 

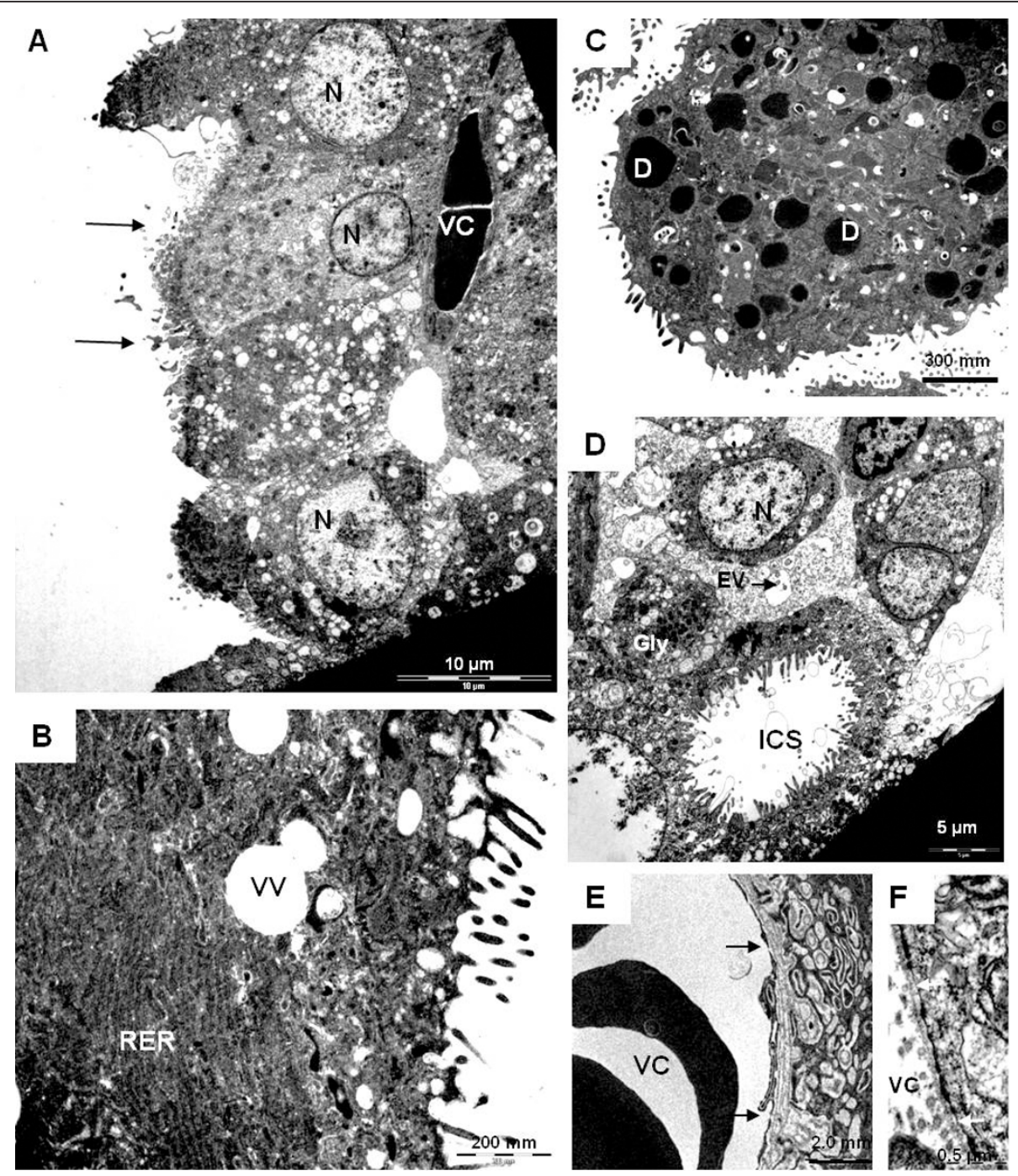

Figure 11 Ultrastructure of the visceral yolk sac in mid gestation. (A) Euryoryzomys (MAV/SJB 02). The endoderm possessed apical microvilli (arrows) and basal nuclei (N). They were close to the vitelline capillaries (VC). (B) Necromys (MZUSP/APC 1246-3). Rough endoplasmic reticulum (RER) and vacuole-like vesicles (W) in the cytoplasm. (C) Necromys (MZUSP/APC 1246-3). Electron-dense inclusions (D). (D) Euryoryzomys (MAV/SJB 02). Glycogen deposits (Gly), endocytic vesicles (EV) and large intracellular spaces (ICS) were evident in the apical cytoplasm. (E) Necromys (MZUSP/APC 1246-3). An endothelial cell of a vitelline capillary with fenestrated regions (arrows). (F) Necromys (MZUSP/APC 1246-3). Higher magnification.

\section{Uterine NK cells}

The uNK cells are the dominant leukocyte population in the gravid uterus of rodents and primates. In human pregnancy they are responsible for the earliest events in spiral artery transformation, which occur prior to trophoblast invasion [45]. In the mouse they play an even greater role in adaptation of the maternal arteries, which fail to widen in the absence of uNK cells [46]. Although murine uNK cells produce a number of cytokines, the key molecule appears to be interferon-gamma [47]. For cricetid rodents, the presence of uNK cells in the walls of transformed spiral arteries was first shown in the golden hamster [13]. We have shown that they are present in large numbers in sigmodont rodents and are similarly associated with the spiral arteries. It is likely that they play an important role in vessel widening and remodeling similar to what has been shown experimentally in the mouse.

\section{Parietal and visceral yolk sac}

The yolk sac was no different in structure from what has been described for other murid and cricetid rodents $[10,14,48-50]$. Recently it was reported [50] that there are no caveolae-like structures in the yolk sac endoderm of the mouse. Likewise, this appears to be the case in Necromys and Euryoryzomys, the two sigmodonts we 
examined by TEM. This is an interesting contrast to what consistently is found in the guinea pig [51] and other hystricognath rodents [e.g. 31,52,53].

\section{Implications for the biology of sigmodont rodents}

The sigmodont rodents reached South America at the time of the Great American Interchange in the Pliocene Epoch or perhaps even earlier [54]. They underwent a rapid radiation that led them to occupy a variety of habitats, including the xeric biomes Cerrado and Caatinga of Brazil $[54,55]$. Despite their potential importance as bioindicators [28] and their undoubted significance as reservoirs of disease [27], they are much less well studied than, for example, the hystricomorph rodents of Latin America (e.g. [30,31,51-53,56-58]).

In most respects placentation in this subfamily closely resembles what has been described for other cricetid rodents $[13,15]$; the close similarity in the fine structure of the interhemal barrier has already been remarked upon. As we have shown elsewhere, the hemotrichorial type of placenta first appeared in the common ancestor or murid and cricetid rodents [39]. Likewise the prominent role of maternal uNK cells in placentation is a feature that sigmodonts share with other cricetid and murid rodents $[13,46]$. The most striking finding in the present material was the relative abundance of trophoblast giant cells first described in Calomys [19] and here extended to a further five genera. In murid rodents giant cells produce a wide range of hormones and cytokines such as proliferin [59] and the significance of the expanded giant cell population in sigmodonts cries for closer attention.

It is, however, unlikely that our understanding of placentation in this subfamily can be further advanced by field studies. It would be better to establish a breeding program and obtain a series of time dated pregnancies from a single species such as Calomys callosus or Necromys lasiurus, both of which have been bred in captivity. The feasibility of such an approach is apparent from an earlier study of trophoblast invasion at the start of pregnancy [17].

\section{Conclusions}

In summary the general aspect of the fetal membranes in Sigmodontinae resembled that found in other cricetid rodents. The chorioallantoic placenta was organized in a labyrinthine zone, junctional zone and decidua and an inverted yolk sac persisted until term. The interhemal barrier was of the hemotrichorial type. The junctional zone was comprised of spongiotrophoblast, glycogen cells and trophoblast giant cells. Compared to murid rodents there were much larger numbers of giant cells and in some genera these were seen to congregate at the periphery of the placental disk. Glycogen cells were found to invade the decidua but we did not identify trophoblast in the walls of the deeper decidual arteries. In contrast these vessels were surrounded by large numbers of uNK cells. This survey of wild-trapped specimens from five genera is a useful starting point for the study of placentation in an important subfamily of South American rodents. We note, however, that some of these rodents can be captive bred and recommend that future studies focus on the study of time dated pregnancies.

\section{Acknowledgements}

We thank Prof. Dr. Mario de Vivo, Curator of Mammals at the Zoology Museum of the University of Sao Paulo, Brazil, for the loan of sigmodontine specimens and Dr. Rodrigo Del Vale and his working group at Sao Joaquim da Barra for providing additional material. We are grateful for technical support to several members of the University Sao Paulo and the Universidade Federal Rural do Semi-Árido, Mossoró, Rio Grande do Norte. This research was supported by grants from FAPESP (Proc. 07/51491-3 and 09/53392-8).

\section{Author details}

${ }^{1}$ Department of Surgery, School of Veterinary Medicine, University of Sao Paulo, Sao Paulo, Brazil. ${ }^{2}$ Cardiovascular and Renal Research, Institute of Molecular Medicine, University of Southern Denmark, Odense, Denmark. ${ }^{3}$ Department of Basic Science, Faculty of Animal Sciences and Food Engineering, University of São Paulo, Pirassununga, Brazil. ${ }^{4}$ Department of Animal Science, Universidade Federal Rural do Semi-Árido, Mossoró, Rio Grande do Norte, Brazil.

\section{Authors' contributions}

AMC and MAM devised the study and participated in its design and coordination. POF performed the major part of the histological analysis. CEA, ACM, MFO and AMM participated in the study design and analysis. AMC, AMM and POF wrote the manuscript. All authors read and approved the final manuscript.

\section{Competing interests}

The authors declare that they have no competing interests.

Received: 3 February 2011 Accepted: 25 April 2011

Published: 25 April 2011

\section{References}

1. Musser GG, Carleton MD: Superfamily Muroidea. In Mammal Species of the World: A Taxonomic and Geographic Reference. Edited by: Wilson DE, Reeder DM. Baltimore: Johns Hopkins University Press; 2005:894-1531.

2. Adamson SL, Lu Y, Whiteley KJ, Holmyard D, Hemberger M, Pfarrer C, Cross JC: Interactions between trophoblast cells and the maternal and fetal circulation in the mouse placenta. Dev Biol 2002, 250:358-373.

3. Coan PM, Conroy N, Burton GJ, Ferguson-Smith AC: Origin and characteristics of glycogen cells in the developing murine placenta. Develop Dynamics 2006, 235:3280-3294.

4. Zhang JH, Yamada AT, Croy BA: DBA-lectin reactivity defines natural killer cells that have homed to mouse decidua. Placenta 2009, 30:968-973.

5. Zhang JH, Chen Z, Smith GN, Croy BA: Natural killer cell-triggered vascular transformation: maternal care before birth? Cell Molec Immunol 2011, 8:1-11.

6. Hu D, Cross JC: Development and function of trophoblast giant cells in the rodent placenta. Int J Dev Biol 2010, 54:341-54.

7. Senner CE, Hemberger M: Regulation of early trophoblast differentiation Lessons from the mouse. Placenta 2010, 31:944-950.

8. Tesser RB, Scherholz PLA, Nascimento L, Katz SG: Trophoblast glycogen cells differentiate early in the mouse ectoplacental cone: putative role during placentation. Histochem Cell Biol 2010, 134:83-92.

9. Vercruysse L, Caluwaerts S, Luyten C, Pijnenborg R: Interstitial trophoblast invasion in the decidua and mesometrial triangle during the last third of pregnancy in the rat. Placenta 2006, 27:22-33. 
10. Mess A: Evolutionary transformations of chorioallantoic placental characters in Rodentia with special reference to hystricognath species. J Exp Zool (Comp Exp Biol) A 2003, 299:78-98.

11. Carpenter SJ: Light and electron microscopic observations on the morphogenesis of the chorioallantoic placenta of the golden hamster (Cricetus auratus). Days seven through nine of gestation. Am J Anat 1972, 135:445-476.

12. Carpenter SJ: Ultrastructural observations on the maturation of the placental labyrinth of the golden hamster (days 10 to 16 of gestation). Am J Anat 1975, 143:315-47.

13. Pijnenborg R, Robertson WB, Brosens I: The arterial migration of trophoblast in the uterus of golden hamster, Mesocricetus auratus. J Reprod Fertil 1974, 40:269-80.

14. Sansom GS: Early development and placentation in Arvicola (Microtus) amphibius, with special reference to the origin of the placental giant cells. J Anat Lond 1922, 56:333-365.

15. King BF, Hastings RA: The comparative fine structure of the interhemal membrane of chorioallantoic placentas from six genera of myomorph rodents. Am J Anat 1977, 149:165-180.

16. Enders AC: A comparative study of the fine structure of the trophoblast in several hemochorial placentas. Am J Anat 1965, 116:29-67.

17. Ferro EAV, Bevilacqua E: Trophoblastic invasion of the uterine epithelium in Calomys callosus (Rodentia, Cricetidae). J Morphol 1994, 221:139-152.

18. Ferro EAV, Bevilacqua E, Favoreto-Junior S, Silva DAO, Mortara RA, Mineo JR: Calomys callosus (Rodentia:Cricetidae) trophoblast cells as host cells to toxoplasma gondii in early pregnancy. Parasitol Res 1999, 85:647-654.

19. Moraes N, Zago D, Gagioti S, Hoshida MS, Bevilacqua E: NADPH-diaphorase activity and nitric oxide synthase isoforms in the trophoblast of Calomys callosus. J Anat 2001, 198:443-453.

20. Ferro EA, Silva DA, Bevilacqua E, Mineo JR: Effect of Toxoplasma gondii infection kinetics on trophoblast cell population in Calomys callosus, a model of congenital toxoplasmosis. Infect Immun 2002, 70:7089-7094.

21. Limongi JE, Ferro EAV: Barreira placentária de Calomys callosus (Rodentia, Cricetidae). Biosc J 2003, 19:89-94.

22. Franco PS, Silva DAO, Costa IN, Gomes AO, Silva ALN, Pena JDO, Mineo JR, Ferro EAV: Evaluation of vertical transmission of Toxoplasma gondii in Calomys callosus model after reinfection with heterologous and virulent strain. Placenta 2011.

23. Weksler M: Phylogeny of Neotropical oryzomyine rodents (Muridae: Sigmodontinae) based on the nuclear IRBP exon. Mol Phylogenet Evol 2003, 29:331-49.

24. Jansa SA, Weksler M: Phylogeny of muroid rodents: relationships within and among major lineages as determined by IRBP gene sequences. Mol Phylogenet Evol 2004, 31:256-276.

25. Weksler M, Percequillo AR, Voss RS: Ten new genera of Oryzomyine rodents (Cricetidae: Sigmodontinae). Am Mus Nov 2006, 3537:1-29.

26. Eisenberg JF, Redford KH: Mammals of the Neotropics. Ecuador, Bolivia, Brazil. Chicago: Chicago University Press; 2000:3:1-624.

27. Figueiredo LT, Moreli ML, de-Sousa RL, Borges AA, de-Figueiredo GG, Machado AM, Bisordi I, Nagasse-Sugahara TK, Suzuki A, Pereira LE, deSouza RP, de-Souza LT, Braconi CT, Harsi CM, de-Andrade-Zanotto PM, Viral diversity Genetic Network Consortium: Hantavirus pulmonary syndrome, central plateau, southeastern, and southern Brazil. Emerg Infect Dis 2009, 15:561-7.

28. Püttker T, Pardini R, Meyer-Lucht $Y$, Sommer S: Response of five small mammal species to micro-scale variations in vegetation structure in secondary Atlantic Forest remnants, Brazil. MBC Ecol 2008, 8:9.

29. Francisco AL, Magnusson WE, Sanaiotti TM: Variation in growth and reproduction of Bolomys lasiurus (Rodentia: Muridae) in an Amazonian savanna. J Trop Ecol 1995, 11:419-428.

30. Oliveira MF, Mess A, Ambrósio CE, Dantas CAG, Favaron PO, Miglino MA Chorioallantoic placentation in Galea spixii (Rodentia, Caviomorpha, Caviidae). Reprod Biol Endocrinol 2008, 6:39.

31. Kanashiro C, Santos TC, Miglino MA, Mess AM, Carter AM: Growth and development of the placenta in capybara (Hydrochaeris hydrochaeris). Reprod Biol Endocrinol 2009, 7:57.

32. Bevilacqua EM, Abrahamsohn PA: Trophoblast invasion during implantation of the mouse embryo. Arch Biol Med Exp 1989, 22:107-118.

33. Georgiades P, Ferguson-Smith AC, Burton GJ: Comparative developmental anatomy of the murine and human definitive placentae. Placenta 2002, 23:3-19.
34. Simmons DG, Fortier AL, Cross JC: Diverse subtypes and developmental origins of trophoblast giant cells in the mouse placenta. Dev Biol 2007, 304:567-578.

35. Coan PM, Ferguson-Smith AC, Burton GJ: Developmental dynamics of the definitive mouse placenta assessed by stereology. Biol Reprod 2004, 70:1806-1813.

36. Simmons DG, Cross JC: Determinants of trophoblast lineage and cell subtype specification in the mouse placenta. Dev Biol 2005, 284:12-24.

37. Hemberger M: Characteristics and significance of trophoblast giant cells. Placenta 2008, 28(Suppl 1):4-9.

38. Hemberger M: Genetic-epigenetic intersection in trophoblast differentiation: implications for extraembryonic tissue function. Epigenetics 2010, 5:24-29.

39. Mess AM, Carter AM: Evolution of the interhaemal barrier in the placenta of rodents. Placenta 2009, 30:914-918.

40. Bouillot $S$, Rampon C, Tillet E, Huber P: Tracing the glycogen cells with protocadherin 12 during mouse placenta development. Placenta 2006, 27:882-888.

41. Zybina TG, Zybina EV: Cell reproduction and genome multiplication in the proliferative and invasive trophoblast cell populations of mammalian placenta. Cell Biol Int 2005, 29:1071-1083.

42. Redline RW, Lu CY: Localization of fetal major histocompatibility complex antigens and maternal leukocytes in murine placenta. Implications for maternal-fetal immunological relationship. Lab Invest 1989, 61:27-36.

43. Caluwaerts S, Vercruysse L, Luyten C, Pijnenborg R: Endovascular trophoblast invasion and associated structural changes in uterine spiral arteries of the pregnant rat. Placenta 2005, 26:574-584.

44. Pijnenborg R: Placentation in the golden hamster (Mesocricetus auratus Waterhouse). Thesis, Katholieke Universiteit Leuven Leuven: acco; 1975, 1-144.

45. Harris LK: Review: Trophoblast-vascular cell interactions in early pregnancy: how to remodel a vessel. Placenta 2010, 31(Suppl 1):S93-S98.

46. Croy BA, Di Santo JP, Greenwood JD, Chantakru S, Ashkar AA: Transplantation into genetically alymphoid mice as an approach to dissect the roles of uterine natural killer cells during pregnancy-a review. Placenta 2000, 21(Suppl A):S77-S80.

47. Monk JM, Leonard S, McBey BA, Croy BA: Induction of murine spiral artery modification by recombinant human interferon-gamma. Placenta 2005, 26:835-838.

48. Jollie WP: Development, morphology, and function of the yolk-sac placenta of laboratory rodents. Teratology 1990, 41:361-81.

49. King BF, Enders AC: Comparative development of the mammalian yolk sac. In The human yolk sac and yolk sac tumors. Edited by: Nogales FF. Berlin: Springer-Verlag; 1993:1-32.

50. Mohanty S, Anderson CL, Robinson JM: The expression of caveolin-1 and the distribution of caveolae in the murine placenta and yolk sac: Parallels to the human placenta. Placenta 2010, 31:144-150.

51. King BF, Enders AC: The fine structure of the guinea pig visceral yolk sac placenta. Am J Anat 1970, 127:397-414.

52. Mess A: Chorioallantoic and yolk sac placentation in the dassie rat Petromus typicus and its significance for the evolution of Hystricognath Rodentia. Placenta 2007, 28:1229-1233.

53. Miglino MA, Franciolli ALR, Oliveira MF, Ambrosio CE, Bonatelli M, Machado MRF, Mess A: Development of the inverted visceral yolk sac in three species of caviids (Rodentia, Caviomorpha, Caviidae). Placenta 2008, 29:748-752.

54. Almeida FC, Bonvicino CR, Cordeiro-Estrela P: Phylogeny and temporal diversification of Calomys (Rodentia, Sigmodontinae): Implications for the biogeography of an endemic genus of the open/dry biomes of South America. Mol Phylogenet Evol 2006, 42:449-466.

55. Bonvicino CR, Lemos B, Weksler M: Small mammals of Chapada dos Veadeiros National Park (Cerrado of Central Brazil): ecologic, karyologic, and taxonomic considerations. Braz J Biol 2005, 65:395-406.

56. Luckett WP: Superordinal and intraordinal affinities of rodents: developmental evidence from the dentition and placentation. In Evolutionary Relationships among Rodents Volume 92. Edited by: Luckett WP, Hartenberger J-L. New York: Plenum Press, NATO ASI-Series; 1985:227-276.

57. Mess A: Development of the chorioallantoic placenta in Octodon degus a model for growth processes in caviomorph rodents? J Exp Zool (Mol Dev Evol) B 2007, 308:371-383.

58. Mess A: The guinea pig placenta: model of placental growth dynamics. Placenta 2007, 28:812-815. 
59. Hemberger M, Nozaki T, Masutani M, Cross JC: Differential expression of angiogenic and vasodilatory factors by invasive trophoblast giant cells depending on depth of invasion. Dev Dyn 2003, 227:185-191.

doi:10.1186/1477-7827-9-55

Cite this article as: Favaron et al:: Placentation in Sigmodontinae: a

rodent taxon native to South America. Reproductive Biology and

Endocrinology 2011 9:55.

Submit your next manuscript to BioMed Central and take full advantage of:

- Convenient online submission

- Thorough peer review

- No space constraints or color figure charges

- Immediate publication on acceptance

- Inclusion in PubMed, CAS, Scopus and Google Scholar

- Research which is freely available for redistribution

Submit your manuscript at www.biomedcentral.com/submit 